\title{
The Speech Act of Greetings in Selected Verses of the Glorious Qur'an: A Socio-Pragmatic Study
}

\author{
Raghda Sabri Rabee \\ Lecturer, Al Jouf University, \\ College of Science \& Arts Al Qurayat, KSA
}

\author{
Fawwaz Al-Abed Al-Haq \\ Vice President for Academic Affairs, \\ Tafila Technical University, Tafilah, Jordan
}

\begin{abstract}
The present study investigates the socio-pragmatic functions of greetings in certain verses of the Glorious Qur'an. It studies Qur'anic greetings contextually within the framework of Austin's and Searle's speech act. To achieve the purpose of the study, 33 utterances of greetings have been chosen from the Glorious Qur'an, collected and translated. Then, these utterances have been classified and analyzed according to the Qur'anic exegeses. Those examples have been divided according to addresser, addressee, and occasion into five types which are Allah's greetings then Angels', Prophets', Muslims', and hypocrites' and infidels'. After having surveyed a fairly representative body of relevant literature, the researchers have found Qur'anic greetings are employed to convey various functions such as: praising, honoring, welcoming, supplicating, carrying glad tidings, appreciating, honorable mention, rich reward, reassurance, establishing friendship and closeness between people who do not know each other, generating mutual love, and a sense of cohesion.
\end{abstract}

Keywords: glorious Qur'an, socio-pragmatics, greetings, functions, Speech Act Theory

\section{Introduction}

Islam is a complete system of life; it covers all aspects of life and offers advice and guidance from birth to death. The Glorious Qur'an constitutes a fertile area of linguistic phenomena that easily lend themselves to linguistic research. In fact, many studies have been conducted on the Glorious Qur'an in terms of speech acts, phonological systems, discourse analysis, syntactic patterns, as well as pragmatic and sociolinguistic functions.

To begin with, it is worth defining the term "socio-pragmatics". Leech (1983, p. 10) defines socio-pragmatics as "the sociological interface of pragmatics". That is, the study of both the forms and functions of language in a given social situation. In other words, socio-pragmatics refers to the social perception underlying participants' interpretation and performance of communicative action.

Glorious Qur'an is the Word of Allah in Arabic which has the highest language style; it is known by its stylistic features and rhetorical devices. It is a challenge for humankind at all levels. It is a miracle revealed upon Prophet Mohammad (peace be upon him). It is considered as the verbal Divine and moral direction for Muslims. Allah promised that He will protect it until the end of time.

This study aims at analyzing the socio-pragmatic functions of greetings which occur in the Glorious Qur'an. In this study, the researchers display different meanings and functions of greetings, observing the common basic

Raghda Sabri Rabee, lecturer, M.A., Department of English Language and Literature, Faculty of Arts, Yarmouk University. Fawwaz Al-Abed Al-Haq, professor, Ph.D., English Department, Tafila Technical University. 
components among them. People can interpret the functions of greetings according to a particular situation and certain circumstances.

\section{Methodology}

The exclusive source of data for this study is the Glorious Qur'an. The researchers have selected illustrative examples that exhibit Qur'anic greetings. The number of the selected samples 33 is adequate for achieving the purpose of this study. Moreover, the researchers have consulted the valuable works of established commentators such as Al-Sabuni in Safwat Al-Tafasir, Ibn-Kathir in Tafsir Al Qur'an Al Azim, Sayid Qutub in Fi Zilal Al-Qur'an, and others to understand the meaning of Qur'anic greeting utterances that are used in this study. The English translations of Qur'anic utterances are taken from Yusuf Ali's (2003): The Meaning of the Holy Qur'an. U.K., Markfield: Islamic Foundation.

In order to achieve the purpose of this study, Qur'anic greeting utterances have been collected and translated. Then, the researchers have determined and classified the functions of Qur'anic greetings depending on the interpretation of a number of contextual parameters such as the addresser, the addressee, and the occasion.

\section{Review of Related Literature}

\section{Greetings and Other Related Speech Acts in English}

Many speech acts are closely related to the speech act of greeting. Examples are apologizing, thanking, congratulating, complimenting, and inviting. The following studies represent these functions.

Malinowski (1923, p. 315) authenticated in Al-Abdul Halim (1994, p. 14) defines "phatic communication" as "a type of speech in which ties of union are created by a mere exchange of words". Thus the expression of greeting such as "How do you do" does not exchange meanings and express ideas, instead, it actually initiates good relationships to fulfill a social function.

Palmer (1976) points out that the social function of language is important as well as the function of carrying information. According to Palmer, asking about the condition of the weather and inquiring about the family are examples of this function. Palmer (1976, p. 40) states "the speaker does not want to know about the health of the family of the man he is talking to, but is simply making social contact".

Song-Cen (1991, p. 55) states "Greeting expressions constitute an important part of the polite language. By greeting, the speaker indicates his attitude towards the addressee or starts a conversation with him". He examines the expressions of greetings in China indicating that greetings are often patterned expressions which may vary among different nations.

Ebsworth and Bodman (1996, p. 89) states "greeting as a speech act is an important discourse function that learners are likely to encounter in a variety of situations". They say "greeting is among the first speech acts that are learned by children in their native languages. Greetings commonly appear in the speech of American English-speaking children between the ages of nine months and eighteen months".

Akindele (2007) examines Sesotho greetings (the spoken language of the people of Lesotho which is an independent landlocked country in Southern Africa), pointing out that greetings are extremely important strategies for the negotiation and control of social identity and social relationships. He maintains "Among the Basotho, greeting is considered as an aid to peaceful social relations because it is very much a part of the daily experience of the group members" (p. 2). He concludes that difference to age, context of situation, and time are powerful factors in organization of Sesotho greetings. 


\section{Greetings and Other Related Speech Acts in Arabic}

Furguson (1967, p. 141) considers greeting expressions as an example of "a politeness formula" (i.e., the formula that uses expressions like good morning, thank you, and bye bye). Each one of these expressions is used in different context. Any of these expressions can be "ironically" used in a wrong context by the speaker for a certain purpose. Furguson (1967) also maintains that the Syrian Arabic formula "SabbaahIlxeer" can be used ironically in the same context as American English "Good Morning". Furthermore, Furguson (p. 147) states that politeness formulas like greetings are important for their presence or absence in a certain context rather than the specific meaning their constituent parts convey.

El-Hassan (1991) examines the Jordanian Arabic of linguistic etiquette used at Jordanian shops. He indicates Arabs open their social discourse with greetings which involve some form of Islamic greeting of peace Asslamualaikum (peace be upon you). He asserts that this pattern of greetings derive the socio-cultural significance from Islam. However, El-Hassan's study does not take into consideration the relation between greetings and religiousness. Therefore, his study lacks empirical evidence.

Al-Addul Halim (1994) analyzes greetings formulas in Jordanian Arabic sociolinguistically. He points out that data are collected from different places such as hospitals and universities. Basically, he investigates the exchange of greetings between professors and students as well as between patients and physicians. Al-Adul Halim (1994) indicates that there are a diversity of greetings formulas and that certain greetings are used among people more than others. He concludes that suitable greeting depends on the addressee. For instance, when students greet their professors with longer greetings than doctors in order to show respect and politeness towards their professors. It seems that the writer is not very much concerned with the pragmatic functions of greetings.

Hazaymeh (2012) studies the different patterns of greetings that are used by Jordanians. He analyzes the different social factors that stand beyond using such patterns, namely, religious, rural, morning, evening, English, the words marhaba and ahlan, silent, and miscellaneous patterns. Moreover, he points out that certain factors such as an environment, Islam, education, media and contact with the West, and relations play a considerable part in choosing greetings in Jordanian Arabic.

This overview reveals that there are no studies that have dealt with greeting utterance in the Glorious Qur'an. This research, thus, is intended to fill the gap in the area of socio-pragmatics.

\section{Meaning of Greetings}

According to Hyper-Dictionary of English, the word "greeting" means "an acknowledgment or expression of good will (especially on meeting)".

Austin (1962, p. 156) considers the "greetings" speech act within "behabitives" by saying: "Behabitives include the notion of reaction to other people's behavior and fortunes and attitudes and expressions to someone else's past conduct or imminence conduct". In his taxonomy, Austin classifies "greeting" as a kind of performatives concerns behavior towards others to exhibit attitude and feelings. Generally, the English word "greet" with its synonymous verb such as "salute" means to express kindness, friendliness, and acknowledgment.

Leech (1983) points out that greetings and other speech acts such as praising, offering, thanking, inviting, and congratulating whose illocutionary force coincides with social goals are intrinsically polite and take the form of positive politeness. Adding another dimension, Leech (1983, p. 104) calls such speech acts as "convivial". This relates to Austin's class of behabitives and Searle's expressives. The illocutionary point of an expressive act 
is to establish an interpersonal relation between the speaker and the hearer because the former expresses a psychological state about a state of affairs that involves the latter.

Bach and Harnish (1979, p. 51) categorize "greeting" as "acknowledgment" to express "perfunctorily if not genuinely" certain feelings towards the hearer. For example, "express pleasure at meeting or seeing someone".

\section{The Structure of Qur'anic Greetings}

As-salamu a'laikum wa-rahmatu Allah "God" wa-barakatu is the most polite Islamic greeting used by Muslims around the world even by Non-Muslims. It is nearly translated to "may the peace be upon you". It is used as a greeting and parting. The standard response is wa-al'aikum as-salam warahmtu Allah wa-barakatuh "may the peace, mercy, and blessing of Allah be upon you". Syntactically, the term in Arabic uses the second person plural masculine, even when used to address one person. A third-person variant, alayhi as-salam "peace be upon him" is used in reference to Prophets (Al-Nijadi, 2007, p. 23).

Moreover, throughout the Qur'an, Allah assures that this is the Islamic greeting by which the true believers will be greeted in Paradise.

\section{Discussion}

This section displays data analysis, findings, and discussion of greetings in the Glorious Qur'an from a socio-pragmatic perspective. This study contains 33 utterances from the Glorious Qur'an which present the greeting meanings and functions. The selected greeting utterances are divided, according to the contextual parameters (addresser, addressee, and occasion), into five types which are:

(1) Allah's Greetings and Salutations;

(2) Angels' Greetings;

(3) Prophets' Greetings;

(4) Muslims' and Believers' Greetings;

(5) Hypocrites and Infidels' Greetings.

To investigate the linguistic phenomenon at hand, the researchers have classified the selected greeting utterances according to their meanings and functions; these functions are also discussed through different examples taken from the Glorious Qur'an.

\section{The Addressers/Addressees of Qur'anic Greetings}

In general, recognizing the participants (addresser/addressee) of any utterance helps the reader to identify the appropriate function which it has. In particular, determining the addresser or the addressee of greetings in the Glorious Qur'an is very important because this helps the reader to know the functions and meanings which they carry. So the researchers have analyzed Qur'anic greetings according to the following addressers/addressees and concluded the appropriate functions for each one.

\section{Allah's Greetings and Salutations}

Belief in Allah constitutes the very foundation of Islam. The true believers recognize that Allah is the Creator and Sustainer of the world, the Originator of life, and the Provider of all things in existence. Faith in Allah and His great power alone can provide mankind with the best possible explanation of many mysterious things in life. Generally speaking, every perfection and absolute goodness belong to Allah (Abdalati, 2010). In this section, 
the researcher illustrates the functions of greeting utterances which are addressed by Allah, through the following illustrative examples:

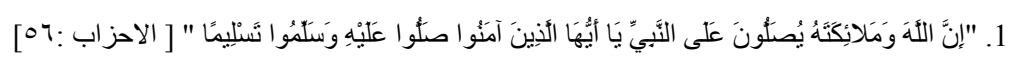

Allah and His angels send blessings on the Prophet: $\mathrm{O}$ you that believe! Send you blessings on him, and salute him with all respect. (Ali, 2003, p. 429)

This utterance is highly meaningful and replete with wisdom. As-Sawi (authenticated by As-Sabuni, 2012) indicates that Prophet Mohammad (PBUH) is the devotee of Allah. Among all of His creation, his rank is the highest and the most reverend. Allah Himself sends salat and salam (blessing and greetings) upon the Prophet Mohammad (PBUH). All worships such as prayer, fasting, pilgrimage, and charity are the commandments of Allah; Allah neither performs prayers nor fasting nor hajj. So the commandment of sending greetings and salutations on Prophet (PBUH) is the most esteemed and glorified act compared to all other worships.

This utterance warns those who give offence to Prophet, either in person or with regard to his family, and showing their action as an enormity. It does so in two ways: (1) honoring the Prophet and describing his status with his Lord and on high and (2) stating that to give offence to Prophet is to give offence to Allah himself. Therefore, it earns the perpetrator expulsion from Allah's mercy both in the present life and in the life to come. Furthermore, the perpetrators stand to suffer a humiliating punishment. Moreover, blessings and greetings upon Prophet (PBUH) by Allah mean that Allah praises and honors him to those on high, by angels that they seek forgiveness and supplication for him, and by people they glorify him. This gives Prophet a sublime position. No honor could be greater than this. How would a prayer and blessing by human beings compare with Allah's own blessing and honor bestowed on Prophet or with those of the angels among the community on high? There is certainly no comparison, but Allah wishes to bestow honor on the believers by putting their greetings upon Prophet together with His own, thus providing them with a tie with those on high (Sayid Qutub, 1971, p. 610).

According to Arabic grammarians, there are two types of sentences; a nominal clause (jumlah ismiyyah) and a verbal clause (jumlah fi'liyya). In fact, a verbal sentence is related to some specific time of any of three specific times (past, present, or future). Thus, time is temporal and transient, whereas, a nominal sentence is not related to time but spreads over all times. In the previous example, the researcher notices that the nominal sentence is used instead of using tense, the past tense or the future. Allah states "إن الله وملائكته يصلون على النبي!". Thus, this utterance indicates that blessings and salutations upon Prophet (PBUH) is an ongoing process and it has a perpetual nature (timelessness).

Furthermore, the example under discussion conveys greeting upon Prophet Mohammad (PBUH) expressing Searle's speech act by using the imperative sentence "وسلموا نسليما" where the gerund follows the verb to emphasize the greetings upon Prophet (PBUH). The addressers of greetings in this utterance are: Allah, then His angels, and then believers, whereas the addressee of greetings is Prophet Mohammad (PBUH). The socio-pragmatic aspect of this utterance is, sending blessings and greetings upon Prophet (PBUH) is the most polite behavior among Muslims used to express the greatness of Prophet Mohammad (PBUH). Praising, honoring, seeking forgiveness, supplicating, glorifying, and appreciating are socio-pragmatic functions of greetings in the previous utterance.

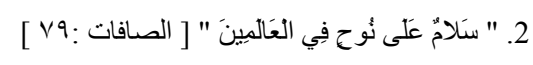

Peace and salutation to Noah among the nations! (Ali, 2003, p. 454) 


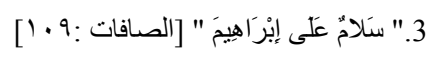

Peace and salutation to Abraham! (Ali, 2003, p. 456)

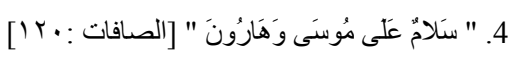

Peace and salutation to Moses and Aaron! (Ali, 2003, p. 456)

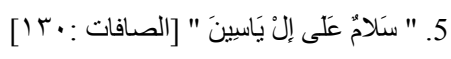

Peace and salutation to such as Elias! (Ali, 2003, p. 457)

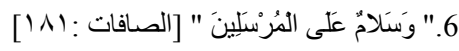

And Peace on the messengers! (Ali, 2003, p. 458)

Salutations upon Prophets are mentioned repeatedly many times in the Glorious Qur'an; sometimes salutations are sent upon all Prophets as in "سلام على المرسلين" other times upon some Prophets by mentioning their names as in "سلام على ابر اهيم" (As-Safl.

This verse (As-Saffat) gives brief accounts of Noah, Abraham, Ishmael and Isaac, Moses and Aaron, and Elias. The first context indicates that only few of Noah's people believed in him, despite the long period of time he spent among them. He stayed among them for one thousand years less fifty. For every time he called upon them, they turned away from him even more. The reference to Noah includes his appeal to Allah saying, "I have been overcome, so help (me)!" and full answer to his prayer that he and his household were saved from the great floods. The utterance " سلام على نوح في العالمين" explains for us the honorable mention and praise since Noah is greeted with peace by all groups and nations. The context then describes Abraham's and Ishmael's story as an example of supreme faith and sacrifice showing us the nature of true surrender to Allah's will. The utterance is a greeting of peace by Allah upon Abraham. The context then refers to Moses and Aaron, highlighting Allah's favor bestowed on them in being chosen to deliver His message and then saving them along with who believed. The context concludes with a greeting and blessing of peace from Allah to them " سلام على "موسى وهارون". Similarly, the context tells the story of Elias, a Prophet of Israel. He followed the same line like Abraham when he called upon his people to worship Allah. The same stance was taken by every messenger when they encountered idol worship. The context ends in the same way like other historical accounts in this verse by emphasizing the honor Allah grants to His messengers by giving them greeting of peace, outlining the reward of people who do good and great value of faith. The verse ends with blessings and greetings of peace to all Allah's messengers (Sayid Qutub, 1971, pp. 57-75).

It is worth mentioning that the situational and linguistic context of the previous utterances indicates that they convey greetings upon Prophets expressing Searle's expressive speech act. The addresser of greetings in the previous examples is Allah Himself, whereas the addressees are Prophets peace be upon them. Moreover, these greetings serve the socio-pragmatic functions of honoring and praising.

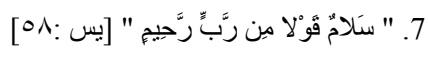

“Peace!"-a word (of salutation) from a Lord Most Merciful! (Ali, 2003, p. 447)

Allah tells us that on the Day of Resurrection, true believers will show their happy end. They are happy, enjoying the fruits served to them, and they are joined by their spouses in perfect enjoyment. Above all of this, they are honored with a greeting of peace from none other than their merciful Allah (Assabuni, 2012, p. 1016). 
It is understood that the previous example implies the speech act of greeting since it belongs to Searle's class of expressive. The addresser of these greetings is Allah Himself, while the addressees are the people of Paradise. Therefore, these greetings convey the socio-pragmatic function of honoring.

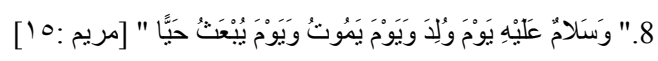

So Peace on him the day he was born, the day that he dies, and the day that he will be raised up to life (again)! (Ali, 2003, p. 305)

The main theme of this verse (Maryam) focuses on Allah's oneness rejecting all concepts and ideas assigning a son or a partner to Him. The verse explores its theme through several stories beginning with that of Zakariyya and his son Yahya and followed with the story of Maryam and the birth of Jesus. The utterance under discussion mentions the noble qualities of Yahya, namely, his obedience to Allah, his good treatment for them, his knowledge, fortitude, and diligence (Ibn-Kathir, 1998, p. 154).

Ibn-Atyya (authenticated by Assabuni, 2012, p. 687) said that the prophet Yahya is greeted with peace in three situations:

- The first situation is on the day that he was born;

- The second situation is on the day that he dies;

- The third situation is on the day when he is resurrected.

These situations are the loneliest that human being will ever feel. Allah has honored Yahya, the son of Zakariyya, by granting him peace in these situations.

The context conveys the explicit speech act of greeting since it belongs to Austin's class of behabitives and Searl's expressive by words in third-person addressed to the prophet Yahya "سلام عليه' . The addresser of greetings in the previous example is Allah Himself and the addressee is Yahya. Therefore, the construction conveys the socio-pragmatic functions of praise, reassurance, and honorable mention to Yahya for his noble qualities.

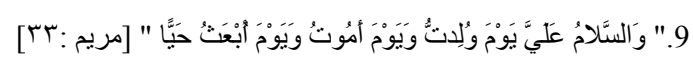

So peace is on me the day I was born, the day that I die, and the day that I shall be raised up to life (again)! (Ali, 2003, p. 306)

This utterance is a declaration that Jesus ('Isah) is a creature created by Allah and he is a prophet, which means that he is neither God's son nor partner as claimed by some sects. He is also enjoined to be very kind towards his mother and to show humility to his people. Allah has blessed him and bestowed on him peace, security, and reassurance on the day of his birth, the day of his death, and the day of his resurrection. The statement here is very clear in respect to the death and resurrection of Juses, just like other creature that Allah has created. However, he will be greeted with peace in these situations, which are the most difficult situations for Allah's creatures (Ibn Kathir, 1998, p. 163).

It can be said that the linguistic context indicates that this utterance is used to express the illocutionary act of greeting since Allah's greetings have their own values. Allah sends His greetings to Jesus using words in first-person. Thus, the addresser of these greetings is Allah Himself, whereas, the addressee is Jesus. The greetings in this utterance express the socio-pragmatic functions of praise, reassurance, and honorable mention for Jesus. 


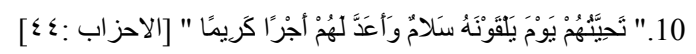

Their salutation on the Day they meet Him will be "Peace!"; and He has prepared for them a generous Reward. (Ali, 2003, p. 427)

This utterance describes the life to come, when the true believers are received there warmly and given honor and rich reward. The apparent meaning is that their greetings, from Allah on the Day that they meet Him, will be salam (peace) to honor them (Ibn-Kathir, 1998, p. 655).

The context indicates that the addresser of greetings in this utterance is Allah Himself, whereas the addressees are the people of Paradise. These greetings covey the socio-pragmatic functions of honor and rich reward.

\section{Angels' Greetings}

It has been denoted that angels also send greetings and salutations. According to Islamic traditions, belief in the existence of angels is the most important matter of faith. Angels in Islam have a very unique appearance; they are created by Allah from light. Angels are different from human beings in that they are not created with a will and therefore they do whatever Allah tells them to do. The Glorious Qur'an speaks about the duties of angels, for instance, praising, glorifying, recording the deeds and statements of human throughout their life, and sending blessings and greetings upon human who are praising Allah and behaving righteously.

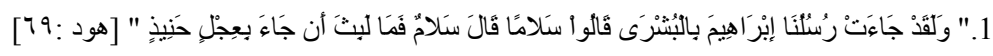

There came Our messengers to Abraham with glad tidings. They said, "Peace!" He answered, "Peace!" and hastened to entertain them with a roasted calf. (Ali, 2003, p. 223)

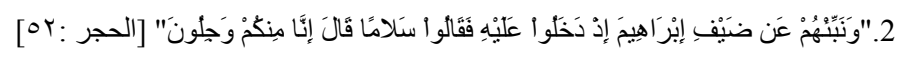

When they entered his presence and said, "Peace!" He said, "We feel afraid of you!” (Ali, 2003, p. 259)

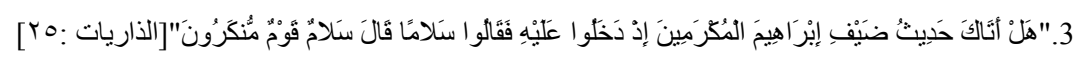

Behold, they entered his presence, and said: "Peace!" He said, "Peace!" (and thought, These seem) unusual people. (Ali, 2003, p. 41)

Some Islamic commentators, such as Sayid Qutub (1971), Ibn Kathir (1998), and Assabuni (2012) point out that many verses of the Glorious Qur'an give a brief history of the people after Noah's time. There is a reference to Abraham's story. The messengers were angels who come with glad tidings. Hence, they greeted him and received his reply. Az-Zammakhashari (2010, p. 273) points out that "the glad tidings" means "Receive the glad tidings of Ishaq". Following the Bedouin tradition of hospitality, Abraham went about preparing food for his guests; he got a fat calf, roasted and prepared it. He presented it to his guests who were angels. Angels do not eat what human beings eat. Thus, they could not partake of the calf and this worried Abraham.

To this day, Bedouins consider it a grave crime to act treacherously towards someone with whom they have shared food. Hence, if they refuse to eat someone's food, their action suggests that they either intend to do harm or that they do not trust the host's intentions. (Az-Zammakhashari, 2010, p. 273)

Therefore, the angels revealed their identity to Abraham and told him about their mission.

Ibn-Kathir (1998, p. 593) points out that some commentators have said that Abraham's reply with the term salamun is better than the angels' greetings using the term salaman because the subjective (salamun instead of salaman) infers affirmation and eternity. 
The contexts give an account of the encounter between Abraham and the angels. This situation is mentioned several times in the Glorious Qur'an, each time in a different way which fits the context in which it occurs. The linguistic context indicates that the previous examples express the speech act of greeting since it belongs to Austin's class of behabitives and Searle's class of expressive by using the explicit performative verb "salaman" and its derivative "salamun". The addressers of greetings in these utterances are the angels and the addressee is Abraham. The socio-pragmatic function of these greetings is carrying the glad tidings.

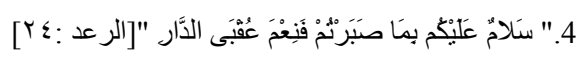

Peace unto you for that you persevered in patience! Now how excellent is the final home! (Ali, 2003, p. 246)

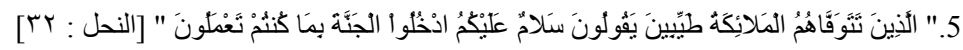

(Namely) those whose lives the angels take in a state of purity, saying (to them) "Peace be on you; enter ye the Garden, because of (the good) which ye did (in the world)". (Ali, 2003, p. 265)

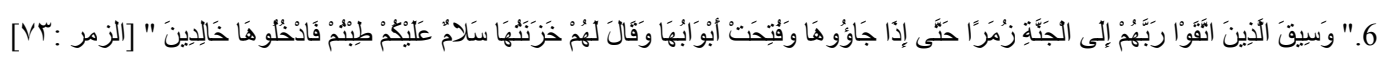

And those who feared their Lord will be led to the Garden in crowds: until behold, they arrive there; its gates will be opened; and its keepers will say: "Peace be upon you! Well have ye done! Enter ye here, to dwell therein". (Ali, 2003, p. 475)

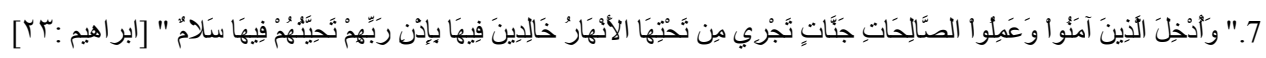

But those who believe and work righteousness will be admitted to gardens beneath which rivers flow,- to dwell therein for aye with the leave of their Lord. Their greeting therein will be:"Peace!". (Ali, 2003, p. 252)

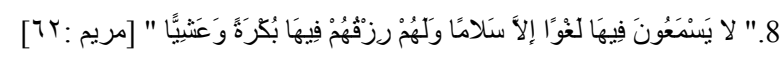

They will not there hear any vain discourse, but only salutations of Peace: And they will have therein their sustenance, morning and evening. (Ali, 2003, p. 308)

$$
9 \text { ـ } 9
$$

Those are the ones who will be rewarded with the highest place in heaven, because of their patient constancy: therein shall they be met with salutations and peace. (Ali, 2003, p. 364)

Some Islamic commentators, such as Sayid Qutub (1971), Ibn Katheer (1998), and Assabuni (2012) point out that many verses of the Glorious Qur'an outline the qualities of the blessed believers. Those fulfill the bond and covenant; the greatest bond is faith. They are good for their righteous relatives; they fear Allah and dread the terrible reckoning. Such people possessing such qualities deserve a good end. In Paradise, the angels take part in their reception and hospitality welcoming the believers saying "سلام عليكم". The people of Paradise enjoy a good life and have a good position. It is a great sight of angels and the believers meeting, greeting, and honoring one another. The angels greet them with a greeting of welcome and reassurance.

The context tells us that the previous examples express the speech act of greeting since it belongs to Austin's

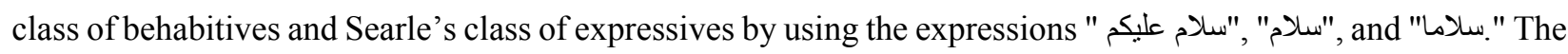
addressers of greetings in utterances under discussion are the angels while the addressees are the people of Paradise. These greetings convey the socio-pragmatic functions of honoring, welcoming, reassurance, rich reward, and congratulation. 


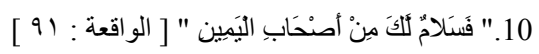

(For him is the salutation), "Peace be unto you", from the Companions of the Right Hand. (Ali, 2003, p. 562)

Sayid Qutub (1971, p. 709) points out that this verse explains the condition of people at the time of their death. These conditions are three types: (1) those who are close to Allah. The soul of such people will now see what awaits it "فروخ وريحانٌ وجنتُ نعيم" (Al-Waq'ah, 1971, p. 89), comfort and happiness; (2) those who are below their rank on the right. Such people are addressed with a greeting of peace sent to them by brethren on the right, "و أما إن كان من أصحاب اليمين" namely, the angels. It is a gentle and delightful greeting giving them reassurance (Al-Waq'ah, 1971, p. 90); and (3) those who denied the truth " وأما إن كان من المكنبين الضالين" (Al-Waq'ah, 1971, p. 92). Such people are led astray from guidance with terrible end suffering from scolding water and blazing fire.

The linguistic context tells us that this utterance expresses the speech act of greeting since it belongs to Austin's class of behabitives and Searle's class of expressive by using the phrase " فَسَلاح" ثلكَ these greetings are brethren who are on the right (the angels), whereas, the addressees are dying people. The socio-pragmatic functions of appreciation of another person, reassurance, and carrying glad tidings are implied by greetings of the previous utterance.

\section{Prophets' Greetings}

In this section, the researcher examines the third type of Qur'anic greetings which is prophet's greetings. According to Arabic dictionaries, Prophets are those people chosen by Allah and assigned a special mission to guide humans; they are given revelation to deliver to mankind. Every prophet is directed a message to preach a different group of people. Prophets are infallible; they do not commit any errors because of their absolute belief. In this section, the researchers will illustrate the socio-pragmatic functions of greeting utterances which are addressed by prophets through the following illustrative examples:

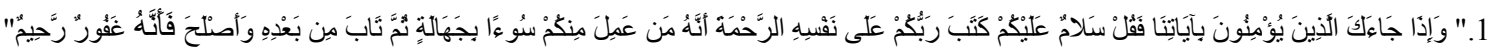

$$
\begin{aligned}
& \text { [0 : الأنعام : }
\end{aligned}
$$

When those come to you who believe in Our signs, Say: "Peace be on you: Your Lord hath inscribed for Himself (the rule of) mercy: Verily, if any of you did evil in ignorance, and thereafter repented, and amend (his conduct), lo! He is Oftforgiving, Most Merciful". (Ali, 2003, p. 134)

The addressee of this utterance is Prophet Mohammad (PBUH). Allah commands him to honor the early Muslims whom Quraysh chiefs ridiculed, with greeting of peace, and to give them glad tidings that Allah grants them His mercy. (Ibn Kathir, 1998, p. 184)

The linguistic context indicates that the previous utterance explicitly expresses the speech act of greeting since it is performed by the statement "سلام عليكم". The addresser of greetings is Prophet Mohammad (PBUH) and the addressees are the early Muslims. The socio-pragmatic functions of honor and carrying glad tidings are conveyed by greetings in the previous example.

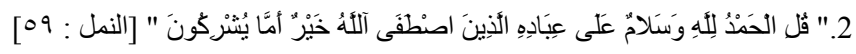

Say: Praise be to Allah, and Peace on his servants whom He has chosen (for his Message). (Who) is better?-Allah or the false gods they associate (with Him)? (Ali, 2003, p. 381)

The addressee of this utterance is Prophet Mohammad (PBUH). Allah orders him to open and conclude his discourse preaching to Allah's message with praising Allah. Thereafter, Prophet Mohammad is commanded to 
send a greeting of peace upon His servants (Noble Prophets) whom He has chosen to deliver His message. (Assabuni, 2012, p. 859)

The linguistic context tells us that the previous example conveys the speech act of greeting since Prophet (PBUH) is explicitly commanded to send a greeting of peace upon other noble prophets by the statement " وسلام ".The socio-pragmatic aspects of greetings in this utterance are: Firstly, to start and conclude discourse preaching and conversation with praising Allah and offering blessings and greetings upon the Noble Prophets (may the best peace and blessings from Allah be upon them). Secondly, these greetings serve the functions of honoring, glorifying, and appreciating.

\section{Muslims' and Believers' Greetings}

In this section, the researchers discuss the forth type of Qur'anic greetings which is Muslim's greetings. In the religious context, Islam means submission to the Will of Allah. Therefore, a Muslim is any human being who accepts, obeys, and submits to Allah's Will, as a follower of Islam (Abdalati, 2010). It is noticed that there are many greeting utterances of the Glorious Qur'an addressed to Muslims. These utterances are clarified in the following examples:

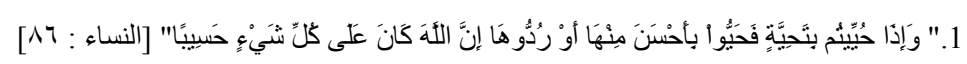

When a (courteous) greeting is offered you, meet it with a greeting still more courteous, or (at least) of equal courtesy. Allah takes careful account of all things. (Ali, 2003, p. 98)

According to Sayid Qutub (1971, p. 471), this utterance gives instructions that a greeting should be answered back with a similar or better one. When a greeting is practiced with politeness, it will be a means of smooth and harmonious social life. Islamic greeting of peace distinguishes Muslim societies and makes Muslims stand out among all other human societies. According to many sayings of Prophet (PBUH), Islam has chosen the following forms of greeting:

(1) Assalamu alaikum (peace be on you), its response is wa 'alaikumassalmuwarahmatullah (and peace and Allah's mercy be on you too);

(2) Assalamu'alaikum warahmatu Allah (peace and Allah's mercy be on you), it answered back with assalamu 'alaikum warahmatu Allah wabarakatuh (peace and Allah's mercy and blessings be on you);

(3) Assalamu 'alaikum warahmatu Allah wabarakatuh (peace and Allah's mercy and blessings be on you), this form is answered back by repeating the same phrase in full.

Furthermore, the context implies that Muslim society has its unique features and traditions, that is to say, it has its own individual laws and systems. The greeting of peace and the better response are one of the best means to achieve close and solid relationships. Moreover, the previous utterance may be intended to point out Islam's fundamental foundation: peace. Islam is the religion of peace and it recommends fighting only in order to establish peace on earth. (Sayid Qutub, 1971, p. 472)

The linguistic context tells us that this utterance expresses the explicit speech act of greeting since it belongs to Austin's class of behabitives and Searle's class of expressives by using the condition “و "واذا حييتم", followed by its

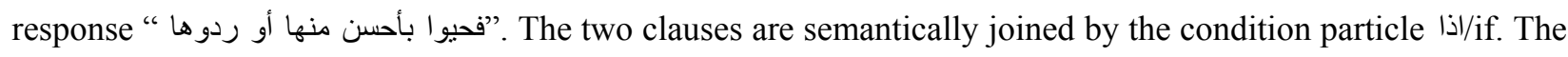
socio-pragmatic aspect of this utterance indicates that spreading greetings and the fulfillment of this social responsibility generates mutual love and a sense of cohesion and removes the climates of tension, hatred, and ill will from hearts. Moreover, greetings establish friendship, brotherhood warmth, and closeness between people who do not know each other. 


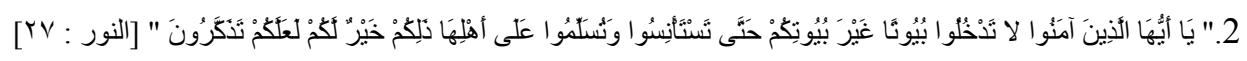

O you who believe! Enter not houses other than your own, until you have asked permission and saluted those in them: That is best for you, in order that you may heed (what is seemly). (Ali, 2003, p. 35)

Allah makes homes for engaging in different types of domestic chores and for resting in seclusion. Women understandably do things at home in a relaxed manner which is not possible for them in the presence of a man not belonging to their household. This utterance teaches the manner of visiting a house. One should offer greetings As-Salam to the host at the doorstep and seek his permission to enter. For instance, whatever one's intention may be, entering another person's dwelling without permission is prohibited (Sayid Qutub, 1971, p. 87).

The context indicates that this utterance expresses the explicit speech act of greeting since it belongs to Austin's class of behabitives and Searle's class of expressives by using the statement "وتسلموا على أهلها". The socio-pragmatic function of permission is conveyed by greetings in the previous example. These greetings prevent disturbing situations. Thus, they are expressions of trust and security among members of a Muslim society.

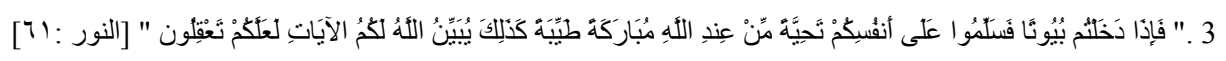

But if you enter houses, salute each other-a greeting of blessing and purity as from Allah. Thus does Allah make clear the signs to you: That ye may understand. (Ali, 2003, p. 356)

This utterance is addressed to Muslims. Early Muslims used to eat in relatives' homes without asking permission. Hence, this utterance has instructions for Muslims when entering their relatives' homes to greet one another with Islamic greeting of peace stating "فنلمو ا على أنفسكم" indicating the strength of the relationship between the early Muslims. When Muslims greet their relatives or friends, they are actually greeting themselves. In doing so, they wish one another pleasant lives. This attitude of the believers is a prayer for goodness, blessing, and peace. Moreover, greetings are expressions of trust and security among Muslims (Sayid Qutub, 1971, p. 125).

The linguistic context indicates that this utterance conveys the speech act of greeting expressing Searle's

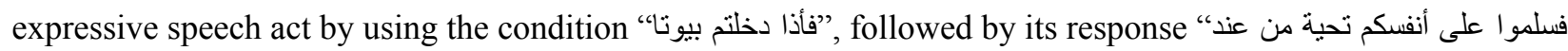

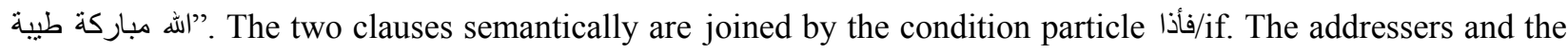
addressees of these greetings are Muslims. The socio-pragmatic aspect of this utterance implies that when Muslims greet their relatives and friends, they pray to Allah for goodness and blessing for them. In addition, these greetings reflect intimacy and solidarity among members of Muslim society.

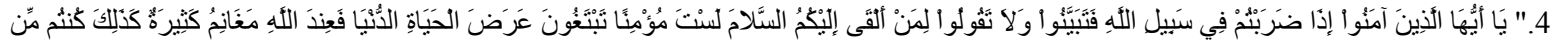

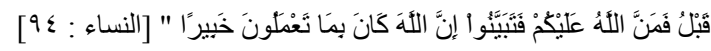

O you who believe! When you go abroad in the cause of Allah, investigate carefully, and say not to anyone who offers you a salutation: "You are none of a believer!" Coveting the perishable goods of this life: With Allah are profits and spoils abundant. Even thus were you yourselves before, till Allah conferred on you His favours: Therefore carefully investigate. For Allah is well aware of all that you do. (Ali, 2003, p. 99)

The occasion on which this utterance was revealed is when a man with his sheep passed by a Muslim expedition; he greeted them with Islamic greeting of peace to indicate that he was a Muslim. Therefore, they killed him. Then, this verse was revealed to indicate that such an action is forbidden. Muslims go to jihad for Allah's cause not for a material gains. Similarly, a hasty judgment may lead to the shedding of a Muslim's blood. 
Thus, their judgments must not be based on a rash decision because Allah provides them a complete system to follow. The context may imply that early Muslims used to conceal from their people the fact that they were Muslims because they were too weak. They only revealed this when they felt secure among other Muslims, offering them the Islamic greeting of peace to indicate that they were Muslims. It can also be understood that this utterance conveys the fact that after having explained its legal system, Islam characterizes external relations between Muslims and other communities (Sayid Qutub, 1971, p. 488).

The linguistic context indicates that this utterance conveys the speech act of greeting since it is performed by the statement "ألقى إليكم السلام". The socio-pragmatic function conveyed by these greetings is asking for peace security and safety from evil. Moreover, Islamic greeting of peace is considered as a sign of Islam.

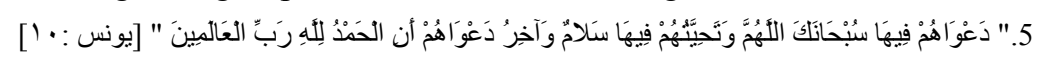

(This will be) their cry therein: "Glory to You, O Allah!" And "Peace" will be their greeting therein! And the close of their cry will be: "Praise be to Allah, the Cherisher and Sustainer of the Worlds!" (Ali, 2003, p. 205)

This utterance portrays the condition of believers in Paradise. Their concerns are not wealth, position, or personal gain. Instead, their top priority is their call to glorify Allah in the beginning and to praise Him in the end. Moreover, angels send their greetings for them while they greet each other with peace. In heaven, believers attain perfection (Ibn Kathir, 1998, p. 537).

The context tells us that the previous utterance expresses the speech act of greeting since the greetings of the people of Paradise have their own values. The addressers of these greetings are angels and the people of Paradise who are at the same time the addressees of greetings when they greet each other. The socio-pragmatic functions of praising, recuperation from evil and imperfection are conveyed by the greetings in the previous utterance.

\section{The People of Al-A'raf's (Heights) Greetings}

In this section, the researchers discuss the fifth type of Qua'anic greetings which is the greetings of the people of Al-A'raf (Heights). Allah assures that there is a barrier between Paradise and Fire over which stand some people whose good deeds are equal in weight and measure to bad ones. Hence, their good deeds qualify them to avoid the Fire and their bad deeds prevent them from admission into Paradise.

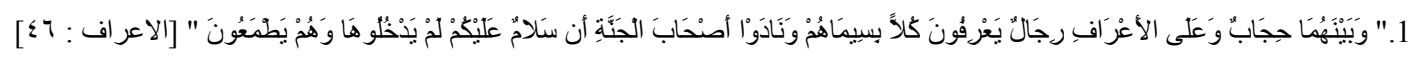

Between them shall be a veil, and on the heights will be men who would know everyone by his marks: they will call out to the Companions of the Garden, "peace on you": they will not have entered, but they will have an assurance (thereof). (Ali, 2003, p. 154)

This utterance talks about the people of Al-A'raf. Those people recognize the people of Paradise by their looks; their faces are white and bright. They also recognize the inmates of Fire by their features; their dark faces . Those people greet the people of Paradise with greeting of peace hoping that Allah will bestow His mercy on them and admit them to Paradise (Assabuni, 2012, p. 381).

The context indicates that the people of Al-A'raf send their greetings to the people of Paradise to congratulate them of being rewarded with Paradise and for hoping to enter it, thus, the socio-pragmatic functions of greetings in the previous example are congratulating and hoping. The previous example expresses the speech act of greeting. The addressers of these greetings are the people of Al-A'raf, whereas, the addressees are the people of Paradise. 


\section{Infidels' and Hypocrites' Greetings}

In this section, the researchers examine the sixth type of Qur'anic greetings which are infidels' and hypocrites' greetings. The term "infidel" is equivalent to the Arabic term "kafir". In general, infidel means "disbeliever". In Islamic sense, infidel is a person who is a disbeliever in Allah, in His oneness and in His last messenger, Mohammad (PBUH). A hypocrite means "a person who professes beliefs and opinions that he or she does not hold in order to conceal his or her feelings or motives". In Islamic sense, "hypocrite" means a person who pretends to be Muslim but he hides hatred and does not believe in Prophet Mohammad (PBUH) and Islam (Islamic Dictionary).

\section{Infidels' Greetings (The Addressees)}

The researchers conclude various functions of Qur'anic greetings from the following examples related to the infidels and hypocrites who are the addressees of greetings:

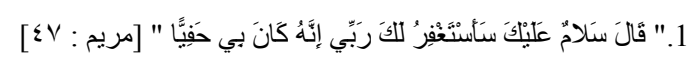

Abraham said: "Peace be on you: I will pray to my Lord for thy forgiveness: for He is to me Most Gracious". (Ali, 2003, p. 307)

The verse (maryam) refers to a part of Abraham's story demonstrating the fallacy of idol worship. The context shows Abraham's contented, patient, and gentle character. They are apparent in his behavior when he addresses his father with passionate appeal, trying to guide him to the goodness Allah had taught him " إذ قال لأبيه يا أبت لم تعبد ما لا يسمع ولا ييصر و لا يغني عنك شيئا (maryam, 1998, p. 42). His argument is based on the basis of true knowledge. However, Abraham's appeal, made with the most compassionate language cannot find its way to his father's hardened heart. His father's answer was harsh, arrogant, and threatening. Abraham does not allow anger to affect his attitude and he also continues to address him with respect and compassion. He promises his father to pray to Allah to forgive him, and he will pray to Allah to have mercy on his father and guide him to the truth saying "سلام عليك". This is due to the respect and honor of fatherhood (Ibn Kathir, 1998, p. 168).

The socio-pragmatic aspect of the previous example indicates that Abraham greets his father with a greeting of peace seeking forgiveness for him due to the respect and honor to fatherhood.

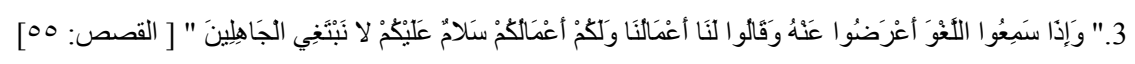

And when they hear vain talk, they turn away there from and say: "To us our deeds, and to you yours; peace be to you: we seek not the ignorant". (Ali, 2003, p. 389)

This utterance speaks about the people of the Book who have already submitted themselves to Allah. Such believers do not engage in laghw (i.e., evil or idle talk without benefit addressed to someone who is present or spoken to when that person is absent). They do not join those who are given to idle talk (infidels). Instead, they maintain an attitude of decency and peace to keep channels open and to keep peaceful relations (Ibn Kathir, 1998, p. 523).

The previous utterance portrays a shining picture of the reassurance faith that draws a clear line to follow whoever wishes to adopt Islamic manner (Sayid Qutub, 1970, p. 360). The context tells us that this utterance expresses the explicit speech act of greetings (parting greetings) by using the expression "سلام عليكم". The socio-pragmatic aspect of this utterance indicates that Muslims maintain an attitude of decency and peace to keep channels open and to keep peaceful relations. 


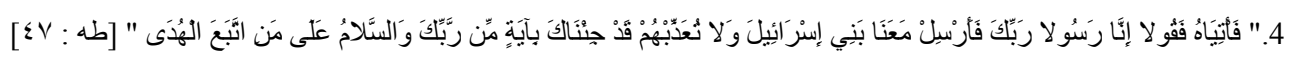

So go you both to him, and say, "Verily we are messengers sent by your Lord: send forth, therefore, the Children of Israel with us, and afflict them not: With a Sign, indeed, have we come from your Lord! And peace to all who follow guidance!" (Ali, 2003, p. 314)

Prophets Moses and Aaron are the direct addressees of this utterance. Allah informs them how they should argue Pharaoh. Firstly, they should start by stating the foundation of their message that they were messengers from his Lord. Secondly, they should explain the immediate concern to save the children of Israel and bring them back with you. Thirdly, they showed Pharaoh the evidence that they were telling the truth that they were messengers from Allah. They follow this with an element of encouragement and hope that he might respond. Allah commands them to greet him by saying "السلام على من اتبع الهذى". It might be that when he had listened to this, he would respond to the greeting of peace and accept Allah's guidance (Sayid Qutub, 1971, p. 476).

The context of the above utterance expresses the explicit speech act of greeting since it belongs to Austin's class of behabitives and Searle's class of expressives by the statement "السلام على من اتبع الهدى". The socio-pragmatic functions of this greeting are to minimize negative feelings to keep channels open and to regularize patterns of mutual behavior among members of speech community. That is to say, Pharaoh might respond to the greeting of peace and accept Allah's guidance.

\section{Hypocrites Greetings With a Twisted Way}

Hypocrites held secret meetings with Jews against Islam. Prophet's policy in dealing with hypocrites was to advise them to be clear and sincere in their attitude. However, they persisted in their deviant ways, conspiring against the Prophet and the Muslim community. In this section, the researchers examine how hypocrites greet Prophet (PBUH) with a twisted way.

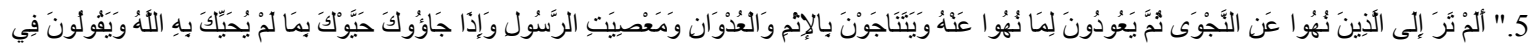

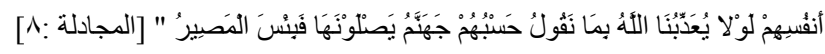

Turn you not your sight towards those who were forbidden secret counsels yet revert to that which they were forbidden (to do)? And they hold secret counsels among themselves for iniquity and hostility, and disobedience to the Messenger. And when they come to you, they salute you, not as Allah salutes you, (but in crooked ways): and they say to themselves, "Why does not Allah punish us for our words?" Enough for them is Hell: In it will they burn, and evil is that destination! (Ali, 2003, pp. 564-570)

The addressee of this utterance is Prophet Mohammad (PBUH). This utterance talks about the hypocrites and Jews who held secret counsels and conspired against Prophet Mohammad (PBUH) and the Muslim community. They persisted in their ways and they used to speak about disobedience of Prophet (PBUH). Assabuni (2012) points out that some of the good interpreters say that Jews used to change the meaning of Islamic greeting. They used to offer their greetings to the Prophet in a twisted way giving a bad statement. They used to pronounce assam 'alaikum which means "death be upon you" instead of Islamic greeting assalamalaikum which means "peace be upon you". Prophet Mohammad (PBUH) has ordered the believers to say in return waalaikum means "and the same on you too" (Assabuni, 2012, p. 1296).

The context tells us that the addressee of greetings in the previous utterance is Prophet Mohammad (PBUH) while the addressers of bad greetings are hypocrites and Jews. The socio-pragmatic function of hypocrites and Jews greeting is manifesting their negative feelings toward Muslims. 


\section{No Greetings for the People of Hell}

Having mentioned the last of the blessed in the previous passage of this verse (saad), Allah follows that with mention of the final return of doomed when they are resurrected and brought to reckoning. In this section, the researchers discuss one sight of those people where life is everlasting:

$$
\text { 6. "هذا فوجُ مقتحمُ معكم لا مرحبأ بهم إنهم صالوا النار * قالوا بل أنتت لا مرحبا بكم أنتم وما قدمتموه لنا فُبُسنَ القرار" [ص:59-60] }
$$

Here is a troop rushing headlong with you! No welcome for them! Truly, they shall burn in the Fire! (The followers shall cry to the misleaders) "Nay, you (too)! No welcome for you! It is you who have brought this upon us! Now evil is (this) place to stay in!” (Ali, 2003, p. 465)

According to Assabuni (2012), Sayid Qutub (1971), and Ibn Kathir (1998), this utterance portrays a scene of the Day of Judgment. A group of infidels who used to have close ties in this World are shown to be exchanging

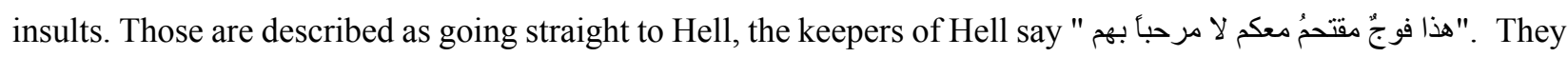
receive an angry and rash answer "لا مرحبا" blaming them for bringing about such fate.

The context tells us that there are no greetings for the people of Hell showing the worst final return.

\section{Conclusion}

This study analyzes the speech act of greeting in the Glorious Qur'an. The researchers collected 32 greeting utterances from the Glorious Qur'an. Those examples are divided into five groups depending on the interpretation of a number of contextual parameters such as (addresser, addressee, and occasion), namely, Allah's greetings and salutations, angels' greetings, prophets' greetings, Muslims' greetings, and infidels' greetings. The collected data have many semantic and linguistic forms, which were classified into socio-pragmatic functions. The current study comes up with the following conclusions:

(1) The study reveals that Qur'anic greetings are significant and meaningful and have socio-pragmatic functions which include polite functions. That is to say, these utterances express the speech act of greeting since it belongs to Austin's class of behabitives and Searle's class of expressive.

(2) As-SalamuA'laikumWa-Rahmatu Allah Wa-Barakatu is the most polite Islamic greeting used by Muslims in this World and Hereafter. Throughout the Qur'an, Allah repeatedly assures us that this is the Islamic greeting of peace. Allah Himself commands us Muslims to greet each other with this greeting.

(3) The analysis shows that the Islamic greeting of peace is a worship meant for establishment of interpersonal relationship and solidarity among people.

(4) It also suggests that the interpretation of contextual parameters such as addresser, addressee, occasion and the purpose of an utterance (expected outcomes of an exchange) are powerful factors in determining the meanings and functions of Qur'anic greetings.

(5) Sending blessings and salutations upon Prophet Mohammad (PBUH) is the most polite behavior among Muslims used to express greatness of Prophet Mohammad (PBUH).

(6) The socio-pragmatic functions of Allah's greetings and salutations are: Praising, honoring, seeking forgiveness, supplication, glorification, appreciation, reassurance, honorable mention, and rich reward.

(7) Allah assures us that true believers who struggle to please Him will be rewarded with peace and security in Paradise, and when they enter Paradise, they will be greeted by the words as-salamua'laikum. Thus, the socio-pragmatic functions of angels' greetings are: Carrying glad tidings, honoring, welcoming, reassurance, 
congratulation, and rich reward for believing servants.

(8) The socio-pragmatic functions of prophets' greetings are: Honoring, giving glad tidings, glorification, appreciation, starting and concluding discourse preaching, conversation, and negotiations with praising Allah and sending blessings upon the prophets to honor, glorify, and appreciate them may the best peace and blessings from Allah be upon them .

(9) The socio-pragmatic functions of Muslims' and believers' greetings are: Establishing friendship, brotherhood warmth, and closeness among people who do not know one another, generating mutual love, a sense of cohesion, and removing the climates of tension, hatred, and ill from hearts. For example, offering greetings for permission when entering somebody's house to prevent disturbing situations. Moreover, the functions of Muslims' greetings are: Congratulation, hope, reassurance, carrying glad tidings, and recuperation from evil, imperfection, and diseases.

(10) The socio-pragmatic function of the prophet Abraham's greetings upon his father (who is infidel) is to show his respect of fatherhood.

(11) The socio-pragmatic functions of greetings among Muslims and Non-Muslims are: Minimizing negative feelings and maintaining an attitude of decency and peace for keeping channels open and for keeping peaceful relations; disbelievers might respond to the Islamic greeting of peace and accept Allah's guidance and to regularize patterns of mutual behavior among members of speech community.

(12) Imperative, condition and declarative are considered as the main components of greeting context.

(13) Qur'anic patterns of address in greeting utterances are: Communicating message directly and through storytelling. The speaker's (Allah) intention is to make peace in the mind of an individual, then in the family, in the community, in the relations between sects, and finally in the relations between countries.

\section{English References}

Abdalati, H. (2010). Islam in focus. Retrieved February 24, 2011 from http://www.islam-infocus.com

Ali, Y. (2003). The meaning of the holy Qur'an. UK, Markfield: Islamic Foundation.

Akindele, D. F. (2007). Lumela/Lumela: A socio-pragmatic analysis of Sesotho greetings. Nordic Journal of African Studies, $16(1), 1-17$.

Al-Abdul Halim, A. (1994). Greetings in Jordanian Arabic: A sociolinguistic study (Unpublished M.A. thesis, Yarmouk University, Jordan).

Al-Khatib, M. A. (1997). Congratulation and thank-you announcements in Jordanian newspapers: Cultural and communicative functions. Language, Culture and Curriculum, 10(2), 156-170.

Al-Khatib, M. A. (2006). The pragmatics of invitation making and acceptance in Jordanian society. Journal of Language and Linguistics, 5(2), 272-294.

Al-Khatib, M. A. (2012). Politeness in the holly Quran: A sociolinguistic and pragmatic perspective. Intercultural Pragmatic, 9(4), 479-509.

Al-Rabee, R. S. (2015). A socio-pragmatic study of greetings in selected verses of the glorious Qur'an (M.A. thesis, Yarmouk University, Jordan).

Austin, J. (1962). How to do things with words. Oxford: Calarendon Press.

Bach, K., \& Harnish, R. (1979). Linguistic communication and speech acts. Cambridge Mass: The MIT Press.

Brown, P., \& Levinson, S. (1978). Universals in language usage: Politeness phenomena. In E. Goody (Ed.), Questions and politeness (pp. 56-280). Cambridge: Cambridge University Press.

Brown, P., \& Levinson, S. (1987). Politeness: Some universals in language usage. Cambridge: Cambridge University Press.

Ebsworth, M. E., \& Bodman, J. W. (1996). Cross-cultural realization of greetings in American English. In S. M. Gass and J. Nue (Eds.), Speech acts across cultures: Challenges to communication in a second language (p. 89). Bertin: Moutonde Gruyter.

El-Hassan, S. (1991). Linguistic etiquette at Jordanian shops. Mu'tah Journal for Research and Studies, 1, 3-48. 
Evans, G. (1982). The varieties of reference. In J. McDowell (Ed.). New York: Oxford University Press.

Farghal, M., \& Al-Khatib, M. (2001). Jordanian college students' responses to compliments: A pilot study. Journal of Pragmatics, 33(9), 1485-1502.

Ferguson, C. A. (1967). The structure and use of politeness formulas. Language in Society, 5, 137-151.

Goffman, E. (1967). Interaction ritual: Essays and face-to-face behavior. New York: Garden City.

Goffman, E. (1971). Relations in public. New York: Colophan Books.

Holmes, J. (1990). Apologies in New Zealand English. Language in Society, 19(2), 155-199.

Hyper-Dictionary of English. (2003). Website design and production by Mega Doc.

Lakoff, R. (1973). The logic of politeness; or minding you P's and Q's. Chicago: Chicago Linguistic Society.

Lakoff, R. (1975). Language and women place (p. 23). New York: Harper and Row.

Leech, G. (1983). Principles of pragmatics. London: Longman.

Levinson, S. (1983). Pragmatics. Cambridge: Cambridge University Press.

Lyons, J. (1977). Semantics. Cambridge: Cambridge University Press.

Marmaridu, S. (2000). Pragmatic meaning and cognition. Amsterdam: John Benjamin Publishing Company.

Palmer, F. R. (1976). Semantics: A new outline. Cambridge: Cambridge University Press.

Requejo, M. (2007). The role of context in word meaning construction: A case study. International Journal of English Studies, $7(1), 160-173$.

Searle, J. (1969). An essay in the philosophy of language. Cambridge: Cambridge University Press.

Searle, J. (1979). Expression and meaning. Cambridge: Cambridge University Press.

Song-Cen, C. (1991). Social distribution and development of greeting expressions in China. International Journal of the Sociology of Language, 92, 55-60.

Yule, G. (2006). The study of language. Cambridge: Cambridge University Press.

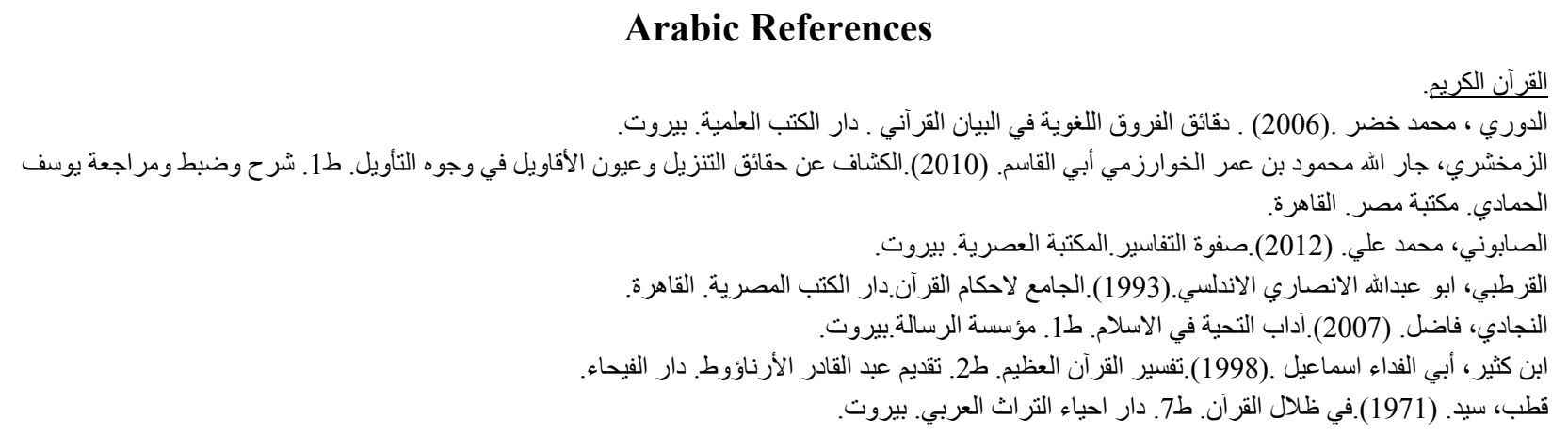




\section{Appendix}

The following table displays 33 Qur'anic examples used in this study in Arabic and its translated meaning in English by Ali Yusuf:

\begin{tabular}{|c|c|c|}
\hline 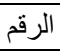 & الآية & السورة ورقم الآية \\
\hline .1 & 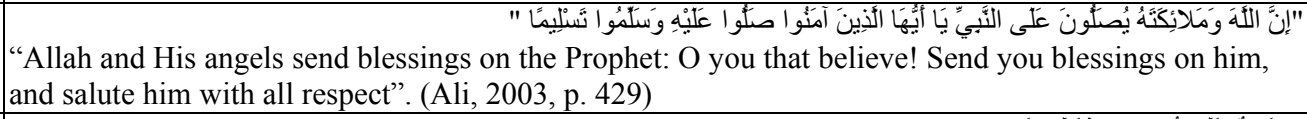 & حز اب :40 \\
\hline .2 & "Peace and salutation to Noah among the nations!" (Ali, 2003, p. 454) & 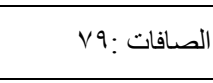 \\
\hline .3 & "Peace and salutation to Abraham!” (Ali, 2003, p. 456) & 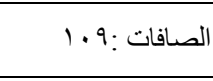 \\
\hline .4 & "Peace and salutation to Moses and Aaron!" (Ali, 2003, p. 456) & 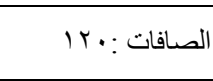 \\
\hline .5 & "Peace and salutation to such as Elias!" (Ali, 2003, p. 457) & 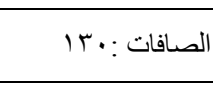 \\
\hline .6 & “"And Peace on the messengers!” (Ali, 2003, p. 458) & 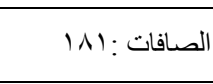 \\
\hline .7 & 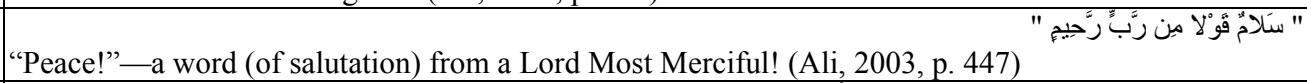 & OA: \\
\hline .8 & 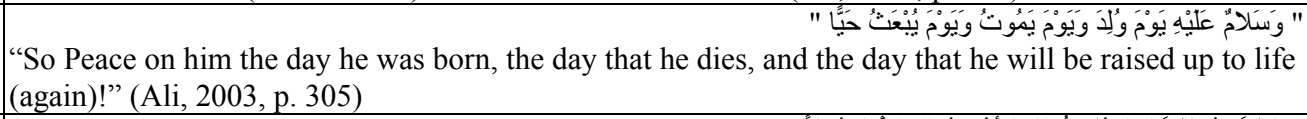 & $10: 5$ \\
\hline .9 & 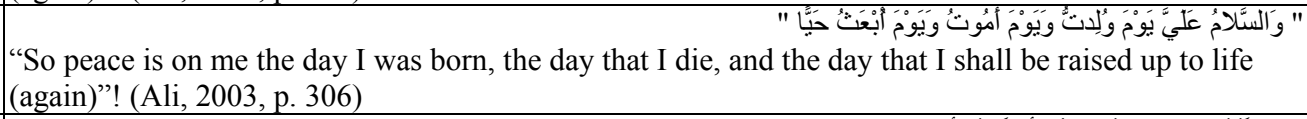 & rt: \\
\hline .10 & 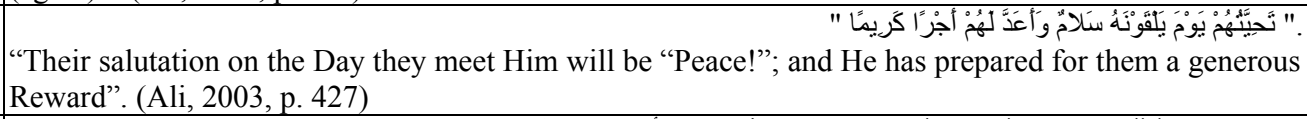 & حز اب :؛ ؛ \\
\hline .11 & 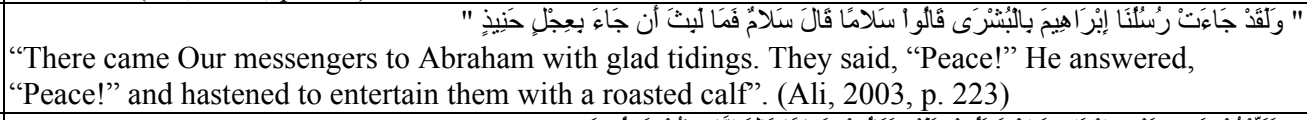 & $79:$ \\
\hline .12 & 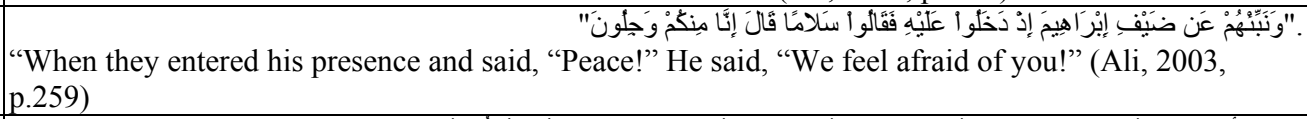 & \\
\hline .13 & 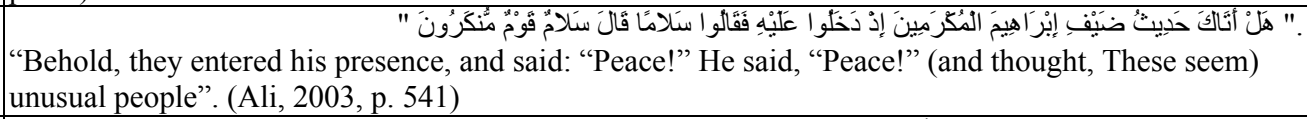 & "اريك :" \\
\hline .14 & 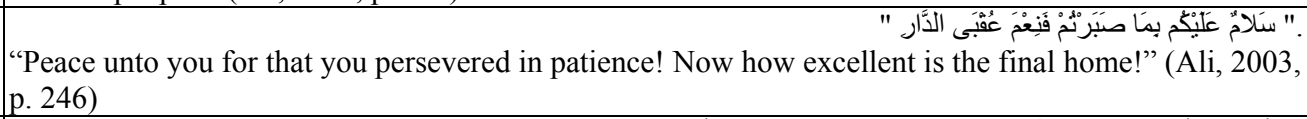 & e \\
\hline .15 & 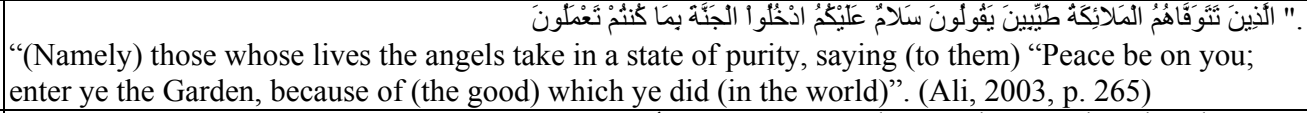 & 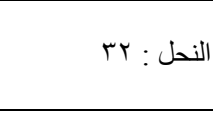 \\
\hline .16 & 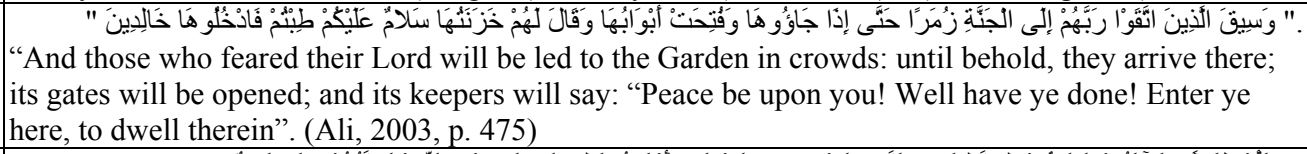 & الز مر . \\
\hline .17 & 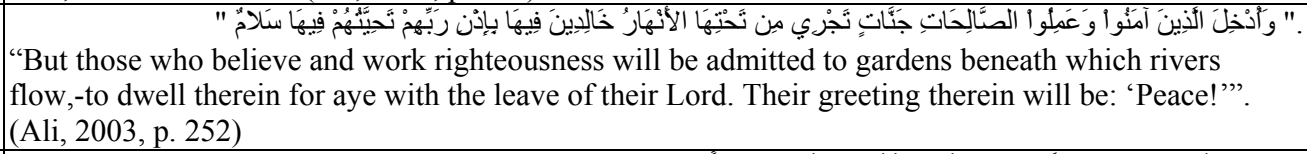 & [ \\
\hline .18 & 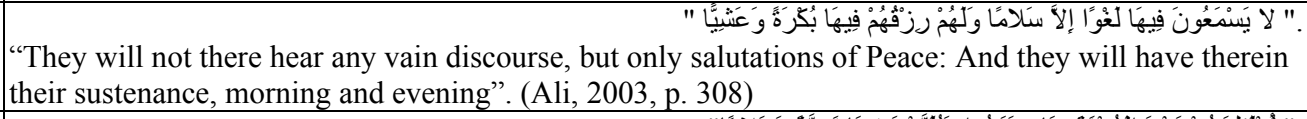 & .8 \\
\hline .19 & 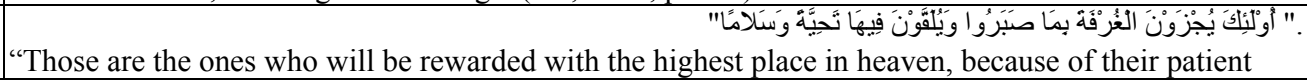 & .0 \\
\hline
\end{tabular}




\begin{tabular}{|c|c|c|}
\hline & constancy: therein shall they be met with salutations and peace". (Ali, 2003, p. 364) & \\
\hline .20 & 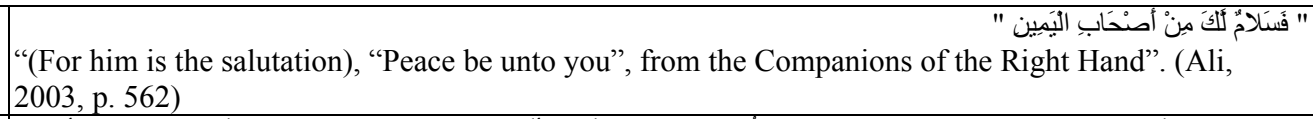 & |الو اقعة : \\
\hline .21 & 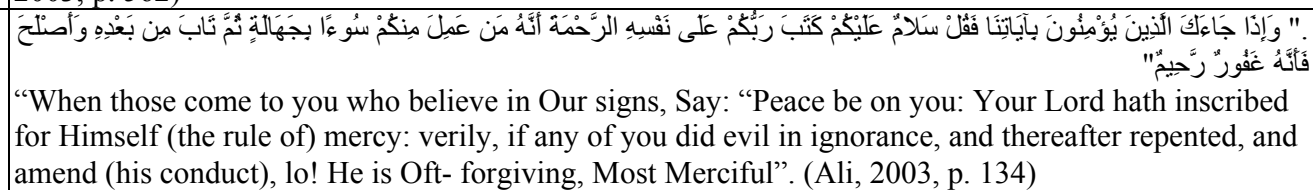 & 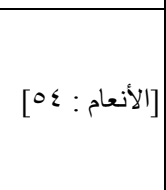 \\
\hline .22 & 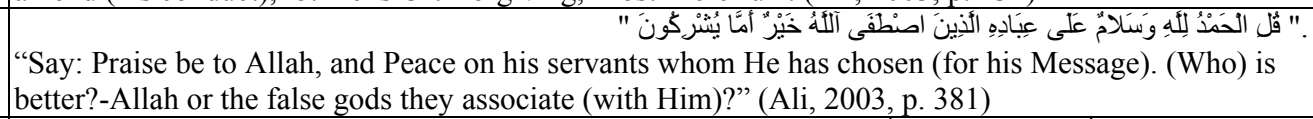 & | النمل : \\
\hline .33 & 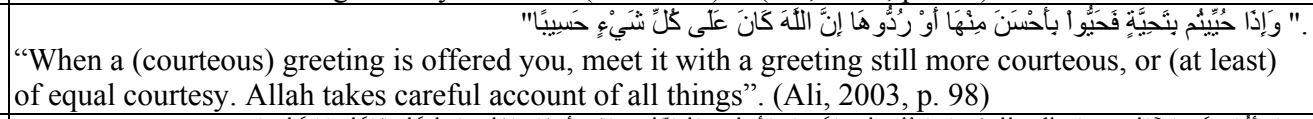 & |النساء: \\
\hline .24 & 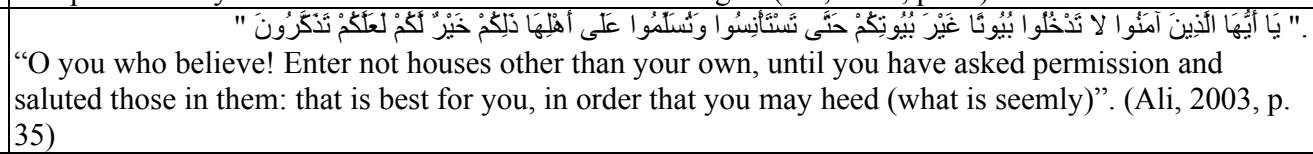 & rv : النور \\
\hline .25 & 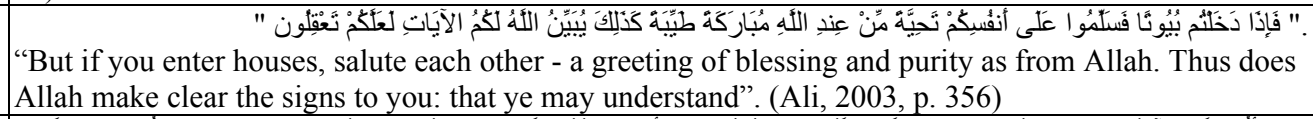 & 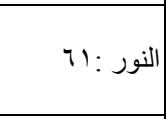 \\
\hline .26 & 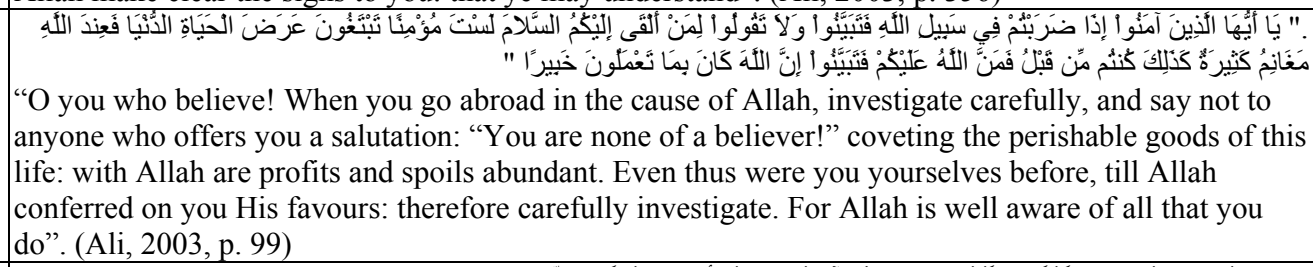 & |النساء : ؟ 9 \\
\hline .27 & 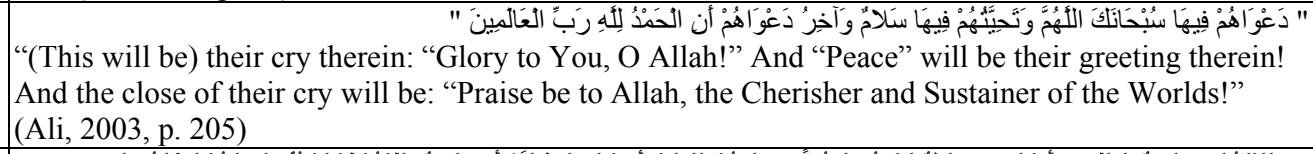 & 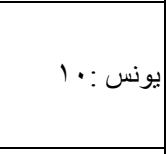 \\
\hline .28 & 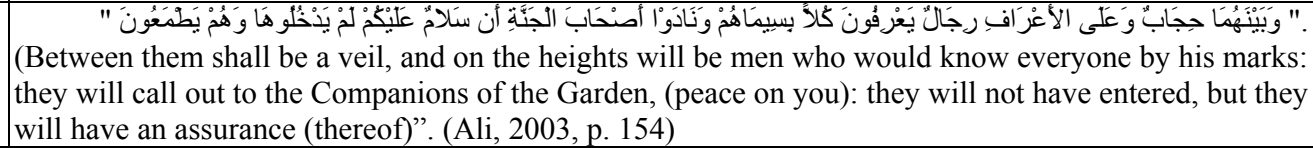 & 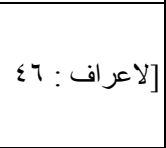 \\
\hline .29 & 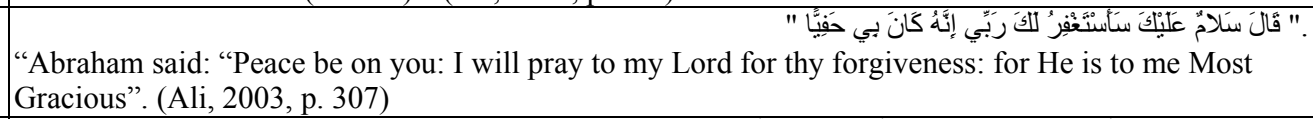 & 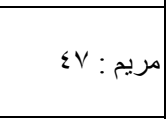 \\
\hline .30 & 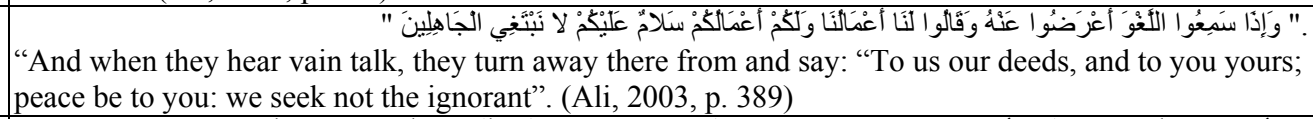 & | (القصص: 000 \\
\hline .31 & 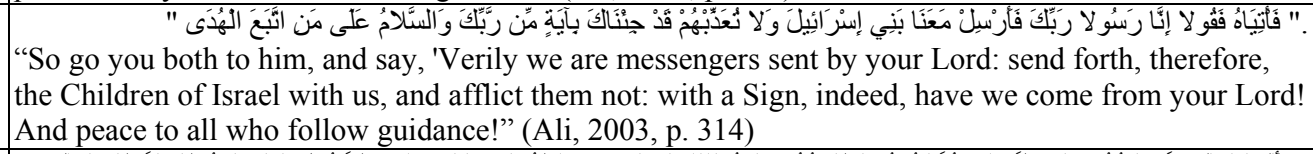 & $\leqslant \vee: ط$ \\
\hline .32 & 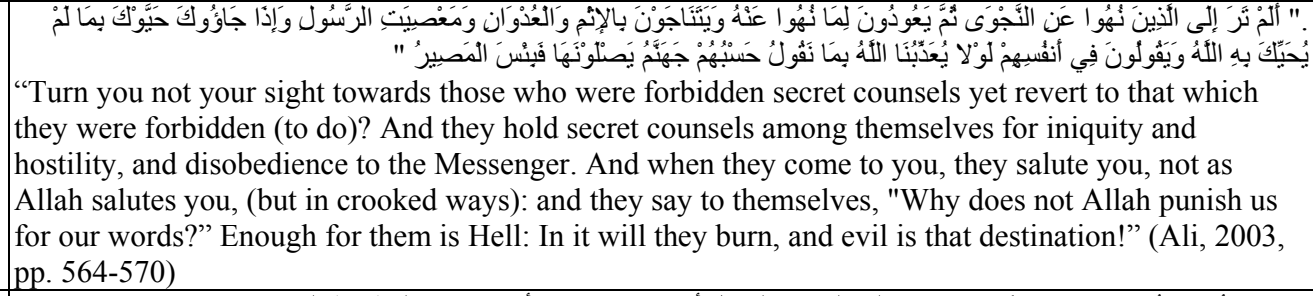 & 1: المجادلة \\
\hline .33 & 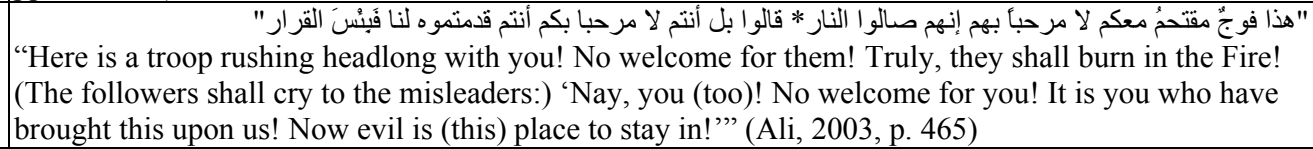 & ص:59-60 \\
\hline
\end{tabular}

